\title{
PERFORMANCE OF RCC BEAMS WITH AND WITHOUT CURTAILMENT
}

\author{
Markandeya Raju Ponnada ${ }^{1}$, Md. Mohsin ${ }^{2}$ \\ ${ }^{1}$ Professor of Civil Engineering, MVGR College of Engineering, Vizianagaram, 535005 (A.P) India, \\ markandeyaraju@gmail.com \\ ${ }^{2}$ P.G student in Structural Engineering, MVGR College of Engineering, Vizianagaram, 535005 (A.P) India. \\ mohsinmd.160@gmail.com
}

\section{SYNOPSIS}

In R.C rectangular beams, theoretically there is no effect of curtailment of steel in flexure. The objective of this work is to establish Load vs Deflection and Load Vs Crack width relationships for RC beams with same Ast but with and without curtailment of tension reinforcement. An experimental study was conducted on 2 RCC beams of $0.23 \mathrm{~m} \times 0.23 \mathrm{~m} \times 1.5 \mathrm{~m}$ size with same Astcorresponding to Moment of Resistance of $40 \mathrm{kN} m$. From the study, it was observed that curtailment improved the Moment carrying capacity and displacement ductility.

Keywords: Curtailment, Area of tension steel, Moment of resistance, deflection, crack width.

\section{INTRODUCTION}

\subsection{General}

Reinforced Cement Concrete is a composite material in which concrete's relatively low tensile strength and ductility are counteracted by the inclusion of reinforcement having higher tensile strength and/or ductility. Reinforcing structures are generally designed to resist tensile stresses in particular regions of the concrete that might cause unacceptable cracking and/or structural failure. The beam is designed by the guidelines of IS 456: 2000. For curtailment of flexural reinforcement, it shall be extended beyond the point at which it is no longer required to resist flexure for a distance equal to the effective depth of the member or 12 times the bar diameter, whichever is greater except at simple support or end of cantilever. A point at which reinforcement is no longer required to resist flexure is where the resistance moment of the section, considering only the continuing bar, is equal to the bending moment. Crack width is a function of steel strain and consequently steel stress. Therefore the stress in the steel reinforcement has to be limited to some extent to prevent cracking from serviceability of the structure. The crack width of a flexural member is calculated to satisfy a limit state of serviceability. The flexural cracks start from the tension face and propagate perpendicular to the axis of the member. Often, curtailment of steel in shear and/or flexure is done for economy. It effects confinement of concrete and hence its performance. However, IS 456: 2000 Code is silent on the quantitative aspects of this phenomenon. This project is an attempt to establish some of these for a typical case.

\section{LITERATURE REVIEW}

Many a researchers conducted studies on RC beams with different reinforcement modes to understand various
parameters.Kulkarni ${ }^{1}$ (2013) conducted experiments on Elastic properties of RCC under flexural loadingexperimental and analytical approach. In this paper AE and EI data is taken to study the elastic property and to plot Load Vs. deflection curves.Kwan ${ }^{2}$ (2006)studied on improving flexural ductility of high-strength concrete beams.Neha ${ }^{3}$ (2014)conducted research on Parametric Study on Reinforced Concrete Beam using ANSYS. In this paper an analytical approach was made stating that by varying the tension steel the initial crack behaviour is not affected but has more impact on post cracking of beams.Saifullah ${ }^{4}$ (2011) studied on nonlinear analysis of RC beam for different shear reinforcement patterns by finite element analysis. They studied beams with various shear reinforcements and stated that all web reinforcements have the same affect for static loading condition. Yasir Alam ${ }^{5}$ (2010) made research on measuring crack width and spacing in reinforced concrete members. They performed bending test on three different beams keeping reinforcement constant and observed that the measured values were almost same as the calculated one, but the size had a significant effect on width and crack spacing. Tejaswi and Eeshwar Ram ${ }^{6}$ (2015) made an experiment investigation on Flexural Behaviour of RCC Beams. Tarek Uddin Mohammed ${ }^{7}$ (2001) did a study on effect of crack width and bar types on corrosion of steel in concrete. This study shows that the relationship between crack width and corrosion rate is observed at very early age of exposure and deformed bars are more prone to corrosion than plain bars. This paper presents a typical case study on the effect of curtailment on the performance of Reinforced concrete beams.

\section{EXPERIMENTAL PROGRAMME}

M40 mix design as per IS 10262: 2009, with 53 grade cement, $20 \mathrm{~mm}$ coarse aggregate and $0.5 \% \mathrm{w} / \mathrm{c}$ ratio was done. The material requirements for M40 grade mix for 
$1 \mathrm{~m}^{3}$ concrete were $400 \mathrm{~kg}$ of cement, 160 lit of water, 1186.4 $\mathrm{kg}$ of coarse aggregate and $672.25 \mathrm{~kg}$ of fine aggregate. Totally 2 beams were cast and each beam having dimension of $0.23 \times 0.23 \times 1.5 \mathrm{~m}^{3}$.

$\mathrm{M}_{\mathrm{u}, \mathrm{lim}}$ was obtained as $44.171 \mathrm{kN}-\mathrm{m}$, and corresponding $\mathrm{A}_{\text {st,lim }}$ was observed to be $658.41 \mathrm{~mm}^{2}$. For $\mathrm{Mu}=40 \mathrm{kN}-\mathrm{m}$, $\mathrm{A}_{\text {st,req }}$ is $580.267 \mathrm{~mm}^{2}$. Therefore $\mathrm{A}_{\text {st,prov }}$ must be between (658.41, 580.267).8mm diameter 2 legged vertical stirrups wereadopted as shear reinforcement with stirrups spacing of $180 \mathrm{~mm}$ (as per IS 456: 2000 design specifications). These details are presented in Table 1 along with bar combinations and percentage of steel. $A_{\text {st }}$ calculation for curtailment of flexure reinforcement for beam B1 along with the bar combinations and percentage of steel are also presented in Table 1.

\section{TEST RESULTS AND DISCUSSION}

The two beams were tested as simply supported beam with central point loadafter 28 days of curing for Moment carrying capacity, deflection and crack width. Table 2 presents the Load vs. Deflection test results of beam B1 along with theoretical short term deflections of the beam as per IS 456:2000.Table 3 presents the crack width measured and theoretical crack width $\left(\mathrm{W}_{\mathrm{cr}}\right)$ as per IS 456:2000for Beam B1. Table 4 and Table 5 present respectively the test results of Theoretical values of short term deflection and the crack width for the curtailed beam B2.Table 6 presents yield load and Ultimate load along with their corresponding deflections and crack width.Figure 1 shows the load Vs. deflection curves for both B1 and B2 beams. Figure 2 shows the load Vs. Crack width curves plotted for both B1 and B2 beams.

Beam B2 showed a gradual increase in deflection parameter.Beam B2 resisted more load than beam B1 showing increase in Moment carrying capacity of the beam.

\section{CONCLUSION}

Inspite of having same reinforcement, the beam with curtailment of Flexure reinforcement i.e., B2, showed increased Moment carrying capacity than beam B1. It deflected more than B1 before failure. Although both the beams have the same $A_{\text {st }}$, the number of bars are high in B2 than in $\mathrm{B} 1$ resulting in high steel- concrete contact area.This may be a factor for enhanced performance of Beam B2.

\section{ACKNOWLEDGEMNTS}

The authors are thankful to the management of MVGR particularly Principal Dr.KVLRaju for all the support and encouragement offered during the course of this project.

\section{REFERENCES}

[1]. $\mathrm{S} \quad \mathrm{K}$ KULKARNI, $\mathrm{M} \quad \mathrm{R}$ SHIYEKAR, $\mathrm{S} \quad \mathrm{M}$ SHIYEKAR and B WAGH "Elastic properties of RCC under flexural loading-experimental and analytical approach"Sadhana, Vol. 39, Part 3, June 2014, pp. 677-697. Indian Academy of Sciences.
[2]. A.K. H. Kwan, S. L. Chau and F. T. K. Au "Improving flexural ductility of high-strength concrete beams" Proceedings Of The Institution Of Civil Engineers StructuresAnd Buildings, 2006, v. 159 n. 6, p. 339-347

[3]. Neha S. Badiger. Kiran M. Malipatil "Parametric Study on Reinforced Concrete Beam using ANSYS"Civil and Environmental Research ISSN 2224-5790 (Paper) ISSN 2225-0514 (Online)Vol.6, No.8, 2014

[4]. Saifullah, M.A. Hossain, S.M.K.Uddin, M.R.A. Khan and M.A. Amin "Nonlinear Analysis of RC Beam for Different Shear Reinforcement Patterns by Finite Element Analysis" International Journal of Civil \& Environmental Engineering IJCEE-IJENS Vol 11 No 01, February 2011.

[5]. Syed YasirAlam, ThibaultLenormand, Ahmed Loukili, J.P. Regoin "Measuring crack width and spacing in reinforced concrete members" 7th International conference on Fracture Mechanics of Concrete and Concrete Structures (FraMCoS-7), May 2010, Jeju, North Korea. pp.377-382.

[6]. S Tejaswi, J Eeshwar Ram "Flexural Behaviour of RCC Beams" International journal of innovations in engineering and technology. volume 5 issue 1 Feb 2015.

[7]. TarekUddin Mohammed, Nobuaki Otsuki, Makoto Hisada and Tsunenori Shibata "Effect of crack width and bar types on corrosion of steel in concrete"journal of materials in civil engineering / may/june 2001 / 201.

[8]. Karthik and Doraikkannan (2015), "Experimental investigation of silica fume and steel slag in concrete", International journal of Mordern Engineering Research, Vol.5, Iss.1, Jan 2015.

[9]. Kucche, Jamkar and sadgir (2015), "Quality of water for making concrete", International Journal of scientific and Research Publications, Vol.5, Issue 1, January 2015.

[10]. Sidhu (2001), "Early age Behaviour of Silica Fume Concrete", $26^{\text {th }}$ conference on our world in concrete andstructures 27-28 August 2001, Singapore, Article online Id 10026071.

[11]. IS 456: 2000, Code practice for plain and reinforced concrete, $4^{\text {th }}$ Revision Bureau of Indian Standards, New Delhi

[12]. IS 10262: 2009, Code of practice for Mix proportioning of Concrete, Bureau of Indian Standards, NewDelhi.

[13]. IS 383: 1987, Specification for coarse and fine aggregate from natural sources for concrete, $8^{\text {th }}$ Reprint October 1991, Bureau of Indian standards, New Delhi.

[14]. IS 516: 1959, Methods of test for strength of concrete, Amendment No. 2, Reprint 1993, Bureau of Indian standards, New Delhi.

[15]. IS 5816: 1999,Splitting tensile strength of concrete, Bureau of Indian standards, New Delhi.

[16]. IS 2386: (Part 3) 1963, Methods of testing for aggregate for concrete, Specific Gravity, Density, 
Absorption and Organic Impurities, Bureau of Indian standards, New Delhi.

[17]. IS 4031: 1988, Method of physical test for hydraulic cement, Bureau of Indian standards, New Delhi.

[18]. IS 12269: 1987 Specification for 53 grade ordinary Portland cement, Bureau of Indian standards, New Delhi.

\section{TABLES AND FIGURES}

Table 1 bar combination and details

\begin{tabular}{|l|l|l|l|l|}
\hline $\begin{array}{l}\text { Bea } \\
\text { m ID }\end{array}$ & $\begin{array}{l}\text { Bar } \\
\text { combinati } \\
\text { ons }\end{array}$ & $\begin{array}{l}\text { Ast(Pro } \\
\text { vided) }\end{array}$ & $\begin{array}{l}\text { Percentage } \\
\text { of steel }\end{array}$ & $\begin{array}{l}\text { Contact } \\
\text { area/ } \\
\text { unit } \\
\text { length }\end{array}$ \\
\hline B1 & $2 \times 20 \varnothing$ & 628.57 & 1.43 & 125.7 \\
\hline B2 & $\begin{array}{l}16 \varnothing+2 \times \\
12 \varnothing\end{array}$ & 628.57 & 1.43 & 125.7 \\
\hline
\end{tabular}

Table 2 Beam B1 experimental and theoretical Deflections

\begin{tabular}{|c|c|c|}
\hline \multirow[b]{2}{*}{ Load in $\mathrm{kN}$} & \multicolumn{2}{|c|}{ Deflection (mm) } \\
\hline & Experimental & Theoretical \\
\hline 13.1 & 0.37 & 0.28 \\
\hline 23.1 & 0.4 & 0.3558 \\
\hline 33.1 & 0.51 & 0.5099 \\
\hline 43.1 & 0.76 & 0.6639 \\
\hline 53.1 & 1.03 & 0.818 \\
\hline 63.1 & 1.36 & 0.972 \\
\hline 73.1 & 1.75 & 1.126 \\
\hline 83.1 & 2.13 & 1.28 \\
\hline 93.1 & 2.46 & 1.43419 \\
\hline 103.1 & 2.76 & 1.5882 \\
\hline 113.1 & 3.03 & 1.74229 \\
\hline 123.1 & 3.38 & 1.8963 \\
\hline 133.1 & 3.69 & 2.0503 \\
\hline 143.1 & 4.04 & 2.2044 \\
\hline 153.1 & 4.39 & 2.3584 \\
\hline 163.1 & 4.78 & 2.5125 \\
\hline 173.1 & 5.29 & 2.666 \\
\hline 183.1 & 6 & 2.8206 \\
\hline
\end{tabular}

Table 3 Beam B1 experimental and theoretical crack widths

\begin{tabular}{|l|l|l|}
\hline Beam B1 & Crack width $(\mathrm{mm})$ & \\
\hline Load in kN & Experimental & Theoretical \\
\hline 13.1 & & 0.03008 \\
\hline 23.1 & & 0.06176 \\
\hline 33.1 & & 0.09344 \\
\hline 43.1 & & 0.1251 \\
\hline 53.1 & & 0.1568 \\
\hline
\end{tabular}

\begin{tabular}{|l|l|l|}
\hline 63.1 & & 0.18847 \\
\hline 73.1 & 0.01 & 0.220156 \\
\hline 83.1 & 0.03 & 0.25183 \\
\hline 93.1 & 0.05 & 0.28351 \\
\hline 103.1 & 0.08 & 0.3468 \\
\hline 113.1 & 0.1 & 0.37854 \\
\hline 123.1 & 0.12 & 0.41022 \\
\hline 133.1 & 0.13 & 0.4419 \\
\hline 143.1 & 0.13 & 0.4735 \\
\hline 153.1 & 0.14 & 0.5052 \\
\hline 163.1 & 0.15 & 0.5369 \\
\hline 173.1 & 0.17 & 0.5686 \\
\hline 183.1 & 2.5 & 0.6002 \\
\hline & & \\
\hline
\end{tabular}

Table 4 Beam B2 experimental and theoretical deflection data

\begin{tabular}{|l|l|l|}
\hline & \multicolumn{2}{|l|}{ Deflection (mm) } \\
\hline Load(kN) & Experimental & Theoretical \\
\hline 13.1 & 0.05 & 0.384 \\
\hline 23.1 & 0.07 & 0.4844 \\
\hline 33.1 & 0.08 & 0.694 \\
\hline 43.1 & 0.31 & 0.9038 \\
\hline 53.1 & 0.5 & 1.1135 \\
\hline 63.1 & 0.89 & 1.3233 \\
\hline 73.1 & 0.95 & 1.533 \\
\hline 83.1 & 1.1 & 1.742 \\
\hline 93.1 & 1.15 & 1.9524 \\
\hline 103.1 & 1.38 & 2.16217 \\
\hline 113.1 & 1.66 & 2.3718 \\
\hline 123.1 & 1.99 & 2.581 \\
\hline 133.1 & 2.3 & 2.7913 \\
\hline 143.1 & 2.66 & 3 \\
\hline 153.1 & 3.04 & 3.2107 \\
\hline 163.1 & 3.55 & 3.4204 \\
\hline 173.1 & 3.89 & 3.63 \\
\hline 183.1 & 4.34 & 3.8399 \\
\hline 193.1 & 5.14 & 4.049 \\
\hline 203.1 & 6.85 & 4.259 \\
\hline 213.1 & 10.1 & 4.469 \\
\hline & & \\
\hline & & \\
\hline
\end{tabular}

Table 5 Beam B2 experimental and theoretical crack width data

\begin{tabular}{|l|l|l|}
\hline Beam B2 & \multicolumn{2}{|l|}{ Crack width $(\mathrm{mm})$} \\
\hline Load $(\mathrm{kN})$ & Experimental & Theoretical \\
\hline 13.1 & & 0.04085 \\
\hline 23.1 & & 0.086 \\
\hline
\end{tabular}




\begin{tabular}{|l|l|l|}
33.1 & & 0.1319 \\
\hline 43.1 & & 0.1774 \\
\hline 53.1 & & 0.2229 \\
\hline 63.1 & & 0.2685 \\
\hline 73.1 & & 0.314 \\
\hline 83.1 & & 0.3596 \\
\hline 93.1 & & 0.40513 \\
\hline 103.1 & & 0.4506 \\
\hline 113.1 & 0.05 & 0.4962 \\
\hline 123.1 & 0.06 & 0.5417 \\
\hline
\end{tabular}

\begin{tabular}{|l|l|l|}
133.1 & 0.08 & 0.5872 \\
\hline 143.1 & 0.09 & 0.6328 \\
\hline 153.1 & 0.5 & 0.6783 \\
\hline 163.1 & 0.6 & 0.7238 \\
\hline 173.1 & 0.8 & 0.894 \\
\hline 183.1 & 1 & 0.8149 \\
\hline 193.1 & 1.01 & 0.8604 \\
\hline 203.1 & 1.11 & 0.906 \\
\hline 213.1 & 1.2 & 0.9515 \\
\hline
\end{tabular}

Table 6 Parameters of Beams B1 and B2

\begin{tabular}{|c|c|c|c|c|c|c|}
\hline & $\begin{array}{c}\text { Yield } \\
\text { load(kN) }\end{array}$ & $\begin{array}{c}\text { Yield } \\
\text { deflection } \\
(\mathrm{mm})\end{array}$ & $\begin{array}{c}\text { Initial } \\
\text { crack } \\
\text { width(mm) }\end{array}$ & $\begin{array}{c}\text { Ultimate } \\
\text { load } \\
(\mathrm{kN})\end{array}$ & $\begin{array}{c}\text { Max. } \\
\text { deflection } \\
(\mathrm{mm})\end{array}$ & $\begin{array}{c}\text { Max. } \\
\text { Crack } \\
\text { width } \\
(\mathrm{mm})\end{array}$ \\
\hline B1 & 73.1 & 0.37 & 0.01 & 183.1 & 6 & 2.5 \\
\hline B2 & 113.1 & 0.05 & 0.05 & 213.1 & 10.1 & 1.2 \\
\hline
\end{tabular}

Figure 1 Load vs. Deflection curves for B1 and B2

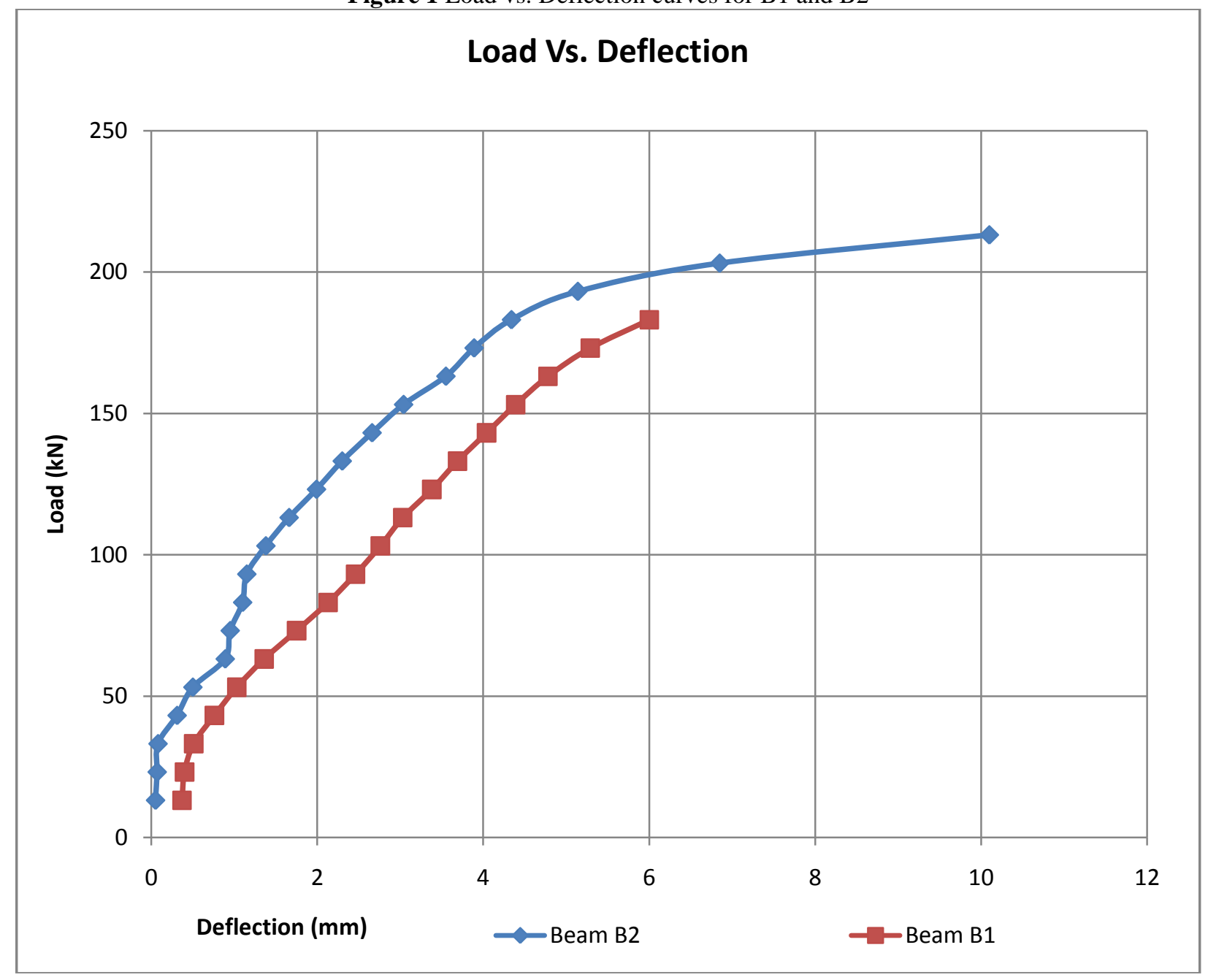


Figure 2 Load vs. Crack width for beam B1 and B2

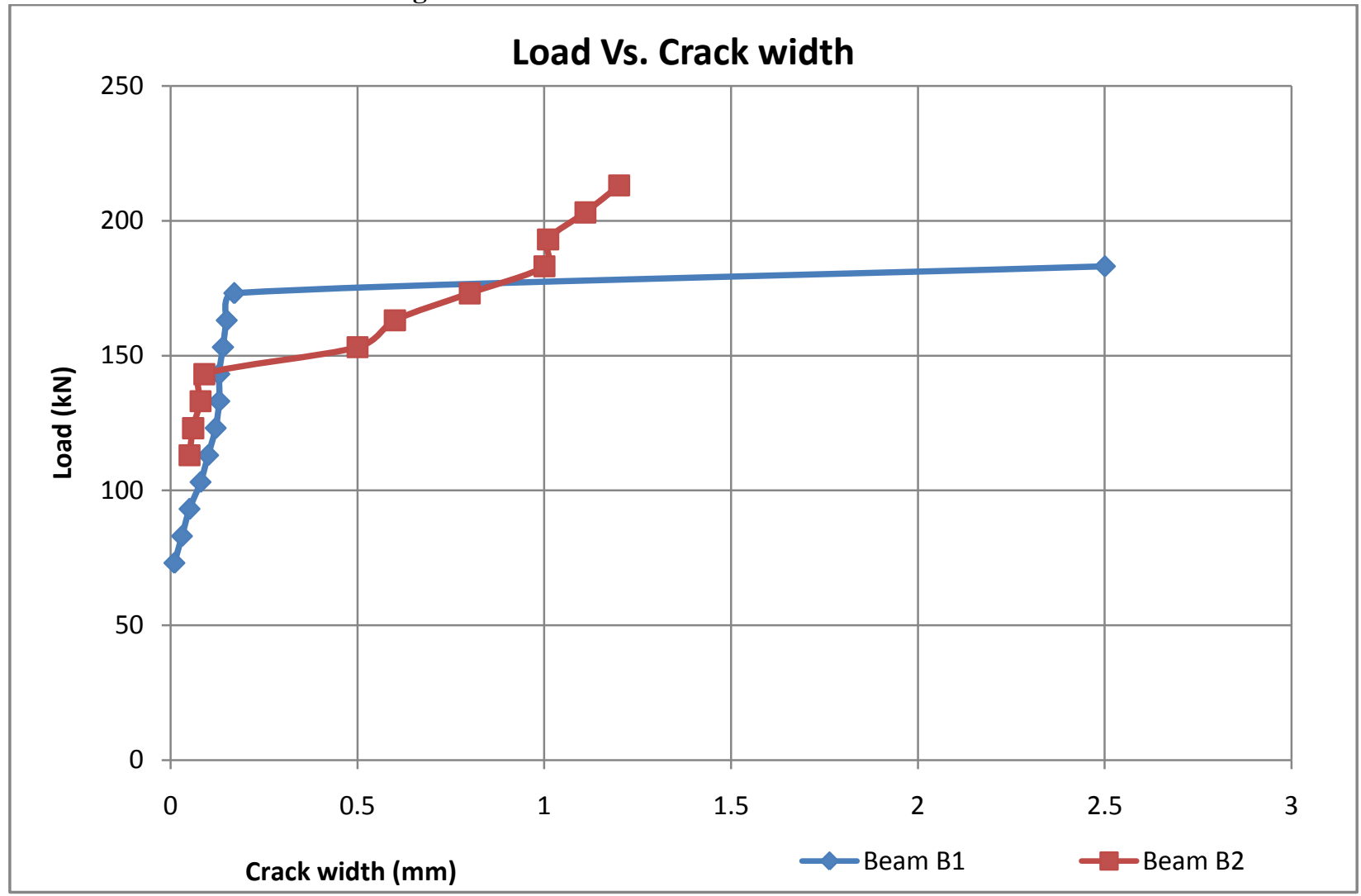

